Artikel Penelitian

\title{
Desain Kinematik Alat Pengumpan Material Berbasis Mekanisme Empat Batang
}

\author{
Syamsul Huda ${ }^{a}$, Muhammad Jihad Islami ${ }^{a}$ dan Mulyadi Bur ${ }^{a}$ \\ Laboratorium Dinamika Struktur Universitas Andalas, Kampus Unand Limau Manis, Padang, 25163
}

\section{INFORMASI ARTIKEL}

\section{Sejarah Artikel:}

Diterima Redaksi: 08 Februari 2019

Revisi Akhir: 22 Maret 2019

Diterbitkan Online: 29 April 2019

\section{KATA KunCI}

Kinematik dan dinamik

Mekanisme empat batang

Peralatan pengumpan material

KORESPONDENSI

E-mail: syamsulhuda@eng.unand.ac.id

\begin{abstract}
A B S T R A C T
In this paper was studied the design of feeding material system using four bars linkage mechanism. It was carried out dimensional synthesis of the mechanism based on the complex number method. This synthesis is applied to determine the length of crank, coupler, follower and dyad that control of feeding weight. Base on the results, it is obtained that the dimension of kinematic constants of the four bars linkage and dyad to control $250 \mathrm{~kg}$ weight of feeding material reprsented by lengths of crank, coupler and follower are $1 \mathrm{~m}, 2 \mathrm{~m}$, and $1 \mathrm{~m}$ respectively and two links of dyad $0.2 \mathrm{~m}$ and $0.75 \mathrm{~m}$. It was also determined the constant of spring to support the opening of the feeding material, $23,18 \mathrm{kN} / \mathrm{m}$ and required input torque, $1083 \mathrm{Nm}$.
\end{abstract}

\section{PENDAHULUAN}

Mekanisme empat batang merupakan suatu mekanisme yang disusun oleh empat batang kaku yang terdiri crank, coupler and follower dan batang diam (ground). Mekanisme jenis ini merupakan mekanisme yang sudah banyak diaplikasikan di berbagai bidang untuk memanipulasi gerak seperti pada peralatan pemesinan, alat pemegang dan pemindah material, peralataan permainan dan lain sebagainya.

Berbagai studi terkait mekanisme ini telah banyak dijumpai baik dalam bentuk publikasi atau paten. Studi mengenai mekanisme ini banyak menyangkut kepada sintesis dimensi. Penelitian terkait metode sintesis untuk memenuhi kriteria gerakan kontinu dari sebuah titik pada coupler telah dikembangkan untuk mendapatkan perbandingan dimensi konstanta-konstanta kinematik yang sesuai [1], [2]. Selanjut sintesis untuk menghasilkan solusi eksak telah dijabarkan dimana sebelumnya sintesis dilakukan berbasis numerik [3].

Di sisi lain perhatian para peneliti terkait sintesis mekanisme ini mengacu kepada optimalisasi disain dengan pertimbangan aplikasi. Rancangan mekanisme empat batang untuk aplikasi peralatan sley drive telah dilakukan dengan pertimbangan optimalisasi sudut transmisi [3]. Pemaanfaatan mekanisme empat batang untuk menggantikan fungsi join revolut untuk aplikasi pengembangan disain rantai kinematik telah dikembangkan [4]. Selanjutnya disain lain terkait aplikasi seperti pada peralatan robot dan alat bantu juga menjadi 
perhatian peneliti untuk mengaplikasikan mekanisme empat batang [5-9].

Pada penelitian ini dikembangkan disain sebuah mekanisme empat yang diterapkan untuk pengontrolan peralatan pengumpan material. Dalam disain ini proses sintesis besar torsi input dijadikan sebagai pertimbangan dalam disain di samping kondisi bukaan katub yang dikontrol oleh follower. Selanjutnya evaluasi konfigurasi mekanisme dilakukan untuk memperoleh konfigurasi yang optimal sehingga dapat ditentukan daya yang dibutuhkan untuk menggerakkan mekanisme tersebut.

\section{TINJAUAN PUSTAKA}

\subsection{Analisis Kinematik}

Ada beberapa macam cara untuk melakukan analisis kinematika dengan metode analisis. Salah satunya yaitu dengan menggunakan metode bilangan kompleks. Disini akan diperlihatkan vektor posisi, kecepatan dan percepatan dalam bentuk bilangan kompleks. Posisi suatu titik pada suatu benda yang berputar dapat diwakili dengan sebuah vektor. Pada Gambar 1 diperlihatkan sebuah batang dalam hal ini diilustrasikan sebagai batang 2 berputar dengan kecepatan $\omega_{2}$ dan percepatan sudut $\alpha_{2}$.

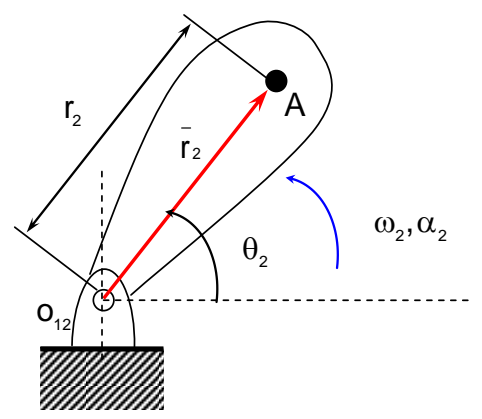

Gambar 1. Batang 2 berputar dengan kecepatan dan percepatan sudut $\omega_{2}$ dan $\alpha_{2}$

Berdasakan parameter yang diberikan pada gambar 1, posisi sebuah titik yang dinyatakan dengan titik A dinyatakan dalam bentuk vektor $\vec{r}_{2}$ dengan bentuk persamaan seperti berikut :

$$
\overrightarrow{\mathrm{r}}_{2}=\mathrm{r}_{2} \mathrm{e}^{\mathrm{i} \theta_{2}}
$$

$\theta_{2}$ merupakan fungsi waktu $t$. Kecepatan titik A diperoleh dengan menurunkan persamaan posisi A terhadap waktu t.

$$
\begin{aligned}
\mathrm{V}_{\mathrm{A}} & =\frac{\mathrm{d}}{\mathrm{dt}}\left(\mathrm{r}_{2} \mathrm{e}^{\mathrm{i} \theta_{2}}\right) \\
& =\mathrm{i} \dot{\theta}_{2} \mathrm{r}_{2} \mathrm{e}^{\mathrm{i} \theta_{2}}
\end{aligned}
$$

Percepatan titik A diperoleh dengan menurunkan persamaan kecepatan titik A terhadap waktu $t$.

$$
\begin{aligned}
\mathrm{A}_{\mathrm{A}} & =\frac{\mathrm{d}}{\mathrm{dt}}\left(\mathrm{i} \dot{\theta}_{2} \mathrm{r}_{2} \mathrm{e}^{\mathrm{i} \theta_{2}}\right) \\
& =\mathrm{i} \ddot{\theta}_{2} \mathrm{r}_{2} \mathrm{e}^{\mathrm{i} \theta_{2}}-\dot{\theta}_{2}{ }^{2} \mathrm{r}_{2} \mathrm{e}^{\mathrm{i} \theta_{2}}
\end{aligned}
$$

Berdasarkan penurunan persamaan (2), dapat dibuat bentuk persamaan kecepatan relatif dua titik pada satu batang kaku dalam hal ini dimisalkan titik A dan B dapat dinyatakan dengan

$$
\begin{aligned}
\mathrm{V}_{\mathrm{B} / \mathrm{A}} & =\frac{\mathrm{d}}{\mathrm{dt}}\left(\overline{\mathrm{AB}} \mathrm{e}^{\mathrm{i} \theta_{2}}\right) \\
= & \mathrm{i} \dot{\theta}_{2} \overline{\mathrm{AB}} \mathrm{e}^{\mathrm{i} \theta_{2}}
\end{aligned}
$$

atau

$$
\begin{aligned}
\mathrm{V}_{\mathrm{A} / \mathrm{B}} & =\frac{\mathrm{d}}{\mathrm{dt}}\left(\overline{\mathrm{AB}} \mathrm{e}^{\mathrm{i}\left(\theta_{2}+\pi\right)}\right) \\
& =i \dot{\theta}_{2} \overline{\mathrm{AB}} \mathrm{e}^{\mathrm{i}\left(\theta_{2}+\pi\right)}
\end{aligned}
$$

Selanjutnya percepatan relatif kedua titik diperoleh dengan menurunkan persamaan (4) atau (5) terhadap waktu, $\mathrm{t}$ yang dapat diekspresikan dengan

$$
\begin{aligned}
\mathrm{A}_{\mathrm{B} / \mathrm{A}} & =\frac{\mathrm{d}}{\mathrm{dt}}\left(\mathrm{i} \dot{\theta}_{2} \overline{\mathrm{AB}} \mathrm{e}^{\mathrm{i} \theta_{2}}\right) \\
= & \mathrm{i} \ddot{\theta}_{2} \overline{\mathrm{AB}} \mathrm{e}^{\mathrm{i} \theta_{2}}-\dot{\theta}_{2}^{2} \overline{\mathrm{AB}} \mathrm{e}^{\mathrm{i} \theta_{2}}
\end{aligned}
$$

Secara umum kecepatan dan percepatan relatif dua titik dapat dituliskan sebagai berikut

$$
\begin{aligned}
& \mathrm{V}_{\mathrm{B}}=\mathrm{V}_{\mathrm{A}} \rightarrow \mathrm{V}_{\mathrm{B} / \mathrm{A}} \\
& \mathrm{V}_{\mathrm{B} / \mathrm{A}}= i \omega_{2} \mathrm{r}_{2} \cos \theta_{2}-\omega_{2} \mathrm{r}_{2} \sin \theta_{2}+\mathrm{i} \omega_{2} \overline{\mathrm{AB}} \cos \theta_{3} \\
&-\omega_{3} \overline{\mathrm{AB}} \sin \theta_{3}
\end{aligned}
$$

$\mathrm{A}_{\mathrm{B}}=\mathrm{A}_{\mathrm{A}} \rightarrow \mathrm{A}_{\mathrm{B} / \mathrm{A}}$ 


$$
\begin{aligned}
\mathrm{A}_{\mathrm{B}}= & \mathrm{i}\left(\alpha_{2} \mathrm{r}_{2} \cos \theta_{2}-\omega_{2}{ }^{2} \mathrm{r}_{2} \sin \theta_{2}\right)-\alpha_{2} \mathrm{r}_{2} \sin \theta_{2}-\omega_{2}{ }^{2} \mathrm{r}_{2} \cos \theta_{2} \\
+ & \mathrm{i}\left(\alpha_{3} \overline{\mathrm{AB}} \cos \theta_{3}-\omega_{3}{ }^{2} \overline{\mathrm{AB}} \sin \theta_{3}\right)-\alpha_{3} \overline{\mathrm{AB}} \sin \theta_{3} \\
& -\omega_{3}{ }^{2} \overline{\mathrm{AB}} \cos \theta_{3}
\end{aligned}
$$

\section{$2.2 \quad$ Analisis Dinamik}

Pada gambar 2 diperlihatkan diagram benda bebas sebuah batang yang berputar pada sebuat titik yang mana batang tersebut disambungkan dengan sambungan engsel. Batang tersebut bergerak dengan kecepatan dan percepatan sudut $\omega_{2} \alpha_{2}$ dengan asumsi pada sambungan tersebut gesekkannya diabaikan. Selanjutnya percepatan pusat massa dinyatakan dengan $\mathrm{A}_{\mathrm{G} 2}$. Batang tersebut berputar dengan pusat rotasi titik $\mathrm{Q}$ dengan sebuah torsi yang bekerja sebesar $\mathrm{T}_{12}$.

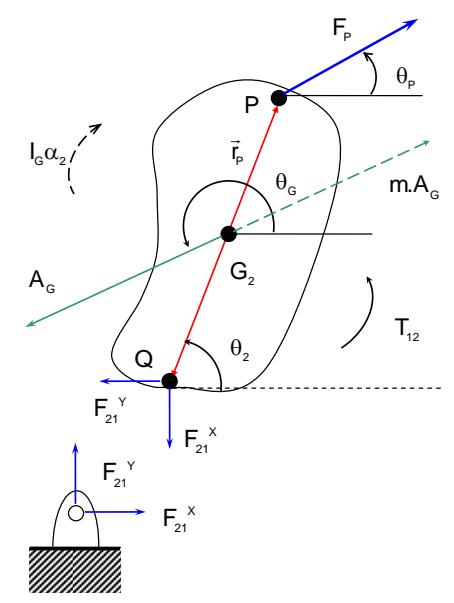

Gambar 2. Diagram benda bebas batang

Dengan mengacu kepada hukum Newton untuk sistem dinamik, hubungan gaya luar dan percepatan dapat dinyatakan dengan:

$\sum \mathrm{F}=\mathrm{m} \cdot \mathrm{a} \quad \sum \mathrm{T}=\mathrm{I}_{\mathrm{G}} \cdot \alpha$

Jika dijabarkan dalam sistem koordinat kartesian dapat dinyatakan dengan

$$
\sum \mathrm{F}_{\mathrm{X}}=\mathrm{m} \cdot \mathrm{a}_{\mathrm{X}} \quad \sum \mathrm{F}_{\mathrm{Y}}=\mathrm{m} \cdot \mathrm{a}_{\mathrm{Y}} \quad \sum \mathrm{T}=\mathrm{I}_{\mathrm{G}} \cdot \alpha
$$

Berdasarkan diagram benda bebas pada pada gambar 4 diperoleh formulasi keseimbangan dinamik yang diformulasikan dalam bilangan kompleks:

$$
\sum \mathrm{F}=\overrightarrow{\mathrm{F}}_{\mathrm{P}}+\overrightarrow{\mathrm{F}}_{12}=\overline{\mathrm{m}_{2} \mathrm{~A}_{\mathrm{G} 2}}
$$

$\sum \mathrm{T}=\mathrm{T}_{12}+\overrightarrow{\mathrm{r}}_{\mathrm{P}} * \overrightarrow{\mathrm{F}}_{\mathrm{P}}+\overrightarrow{\mathrm{r}}_{2} * \overrightarrow{\mathrm{F}}_{12}=\mathrm{I}_{\mathrm{G}} \cdot \alpha$

Dimana

$$
\begin{aligned}
& \overrightarrow{\mathrm{F}}_{\mathrm{P}}=\mathrm{F}_{\mathrm{P}} \mathrm{e}^{\mathrm{i} \theta_{\mathrm{p}}}=\mathrm{F}_{\mathrm{P}}\left(\cos \theta_{\mathrm{P}}+\mathrm{i} \sin \theta_{\mathrm{P}}\right) \\
& \overrightarrow{\mathrm{F}}_{12}=-\mathrm{F}_{12 \mathrm{X}}-\mathrm{iF}_{12 \mathrm{Y}} \\
& \overrightarrow{\mathrm{r}}_{\mathrm{P}}=\overrightarrow{\mathrm{G}_{2} \mathrm{P}} \mathrm{e}^{\mathrm{i} \theta_{2}} \\
& \overrightarrow{\mathrm{r}}_{2}=\overrightarrow{\mathrm{G}_{2} \mathrm{Q}} \mathrm{e}^{\mathrm{i}\left(\theta_{2}+\pi\right)}=\overrightarrow{\mathrm{G}_{2} \mathrm{Q}} \mathrm{e}^{\mathrm{i} \theta_{2}}=\overrightarrow{\mathrm{G}_{2} \mathrm{Q}} \cos \theta_{2}+\mathrm{iG}_{2} \mathrm{Q} \sin \theta_{2}
\end{aligned}
$$

Sehingga persamaan (12) dapat dituliskan menjadi

$$
\begin{aligned}
\mathrm{F}_{\mathrm{P}}\left(\cos \theta_{\mathrm{P}}+\mathrm{i} \sin \theta_{\mathrm{P}}\right)+\mathrm{F}_{12 \mathrm{X}}+\mathrm{iF}_{12 \mathrm{Y}}= \\
\mathrm{m}_{2} \mathrm{~A}_{\mathrm{G} 2}\left(\cos \theta_{\mathrm{G} 2}+\mathrm{i} \sin \theta_{\mathrm{G} 2}\right)
\end{aligned}
$$

Dengan pemisahan komponen riil dan imajinernya, diperoleh:

$$
\begin{aligned}
& \mathrm{F}_{\mathrm{P}} \cos \theta_{\mathrm{P}}+\mathrm{F}_{12 \mathrm{X}}=\mathrm{m}_{2} \mathrm{~A}_{\mathrm{G} 2} \cos \theta_{\mathrm{G} 2} \\
& \mathrm{~F}_{\mathrm{P}} \sin \theta_{\mathrm{P}}+\mathrm{F}_{12 \mathrm{Y}}=\mathrm{m}_{2} \mathrm{~A}_{\mathrm{G} 2} \sin \theta_{\mathrm{G} 2}
\end{aligned}
$$

Persamaan torsi di atas menjadi

$$
\begin{aligned}
\mathrm{T}_{12}+\overrightarrow{\mathrm{F}}_{\mathrm{P}} * \overrightarrow{\mathrm{G}_{2} \mathrm{p}} \sin \left(\theta_{\mathrm{P}}-\theta_{2}\right)+\overrightarrow{\mathrm{G}_{2} \mathrm{Q}} \cos \theta_{2} * \mathrm{~F}_{12 \mathrm{Y}} \\
-\overrightarrow{\mathrm{G}_{2} \mathrm{Q}} \sin \theta_{2} * \mathrm{~F}_{12 \mathrm{X}}=\mathrm{I}_{\mathrm{G}} \alpha
\end{aligned}
$$

Dimana:

$$
\overrightarrow{\mathrm{r}}_{2} * \overrightarrow{\mathrm{F}}_{12}=\mathrm{F}_{12 \mathrm{Y}} * \overrightarrow{\mathrm{G}_{2} \mathrm{Q}} \cos \theta_{2} * \mathrm{~F}_{12 \mathrm{Y}}-\overrightarrow{\mathrm{G}_{2} \mathrm{Q}} \sin \theta_{2} \mathrm{~F}_{12 \mathrm{X}}
$$

Persamaan (19) - (20 ) disusun kembali menjadi

$$
\begin{gathered}
\mathrm{F}_{12 \mathrm{X}}=\mathrm{m}_{2} \mathrm{~A}_{\mathrm{G} 2} \cos \theta_{\mathrm{G} 2}-\mathrm{F}_{\mathrm{P}} \cos \theta_{\mathrm{P}} \\
\mathrm{F}_{12 \mathrm{Y}}=\mathrm{m}_{2} \mathrm{~A}_{\mathrm{G} 2} \sin \theta_{\mathrm{G} 2}-\mathrm{F}_{\mathrm{P}} \sin \theta_{\mathrm{P}} \\
\mathrm{T}_{12}+\overline{\mathrm{G}_{2} \mathrm{Q}} \cos \theta_{2} * \mathrm{~F}_{12 \mathrm{Y}}-\overline{\mathrm{G}_{2} \mathrm{Q}} \sin \theta_{2} * \mathrm{~F}_{12 \mathrm{X}} \\
=\mathrm{I}_{\mathrm{G}} \alpha-\overrightarrow{\mathrm{F}}_{\mathrm{P}} * \overrightarrow{\mathrm{G}_{2} \mathrm{p}} \sin \left(\theta_{\mathrm{P}}-\theta_{2}\right) \\
{\left[\begin{array}{rrr}
1 & 0 & 0 \\
0 & 1 & 0 \\
-\overrightarrow{\mathrm{G}_{2} \mathrm{Q}} \sin \theta_{2} & \overrightarrow{\mathrm{G}_{2} \mathrm{Q}} \cos \theta_{2} & 1
\end{array}\right]\left\{\begin{array}{c}
\mathrm{F}_{12 \mathrm{X}} \\
\mathrm{F}_{12 \mathrm{Y}} \\
\mathrm{T}_{12}
\end{array}\right\}} \\
=\left\{\begin{array}{l}
\mathrm{m}_{2} \mathrm{~A}_{\mathrm{G} 2} \cos \theta_{\mathrm{G} 2}-\mathrm{F}_{\mathrm{P}} \cos \theta_{\mathrm{P}} \\
\mathrm{m}_{2} \mathrm{~A}_{\mathrm{G} 2} \sin \theta_{\mathrm{G} 2}-\mathrm{F}_{\mathrm{P}} \sin \theta_{\mathrm{P}} \\
\mathrm{G} \alpha-\overrightarrow{\mathrm{F}}_{\mathrm{P}} * \overrightarrow{\mathrm{G}_{2} \mathrm{p}} \sin \left(\theta_{\mathrm{P}}-\theta_{2}\right)
\end{array}\right\}
\end{gathered}
$$


3

\section{METODOLOGI}

Pada penelitian ini dianalisis sebuah mekanisme pengumpanan material curah. Mekanisme ini dapat dimodelkan dengan mekanisme kontak dua buah roda gigi dan gabungan antara mekanisme empat batang dengan engkol peluncur, seperti terlihat pada Gambar 3. Prinsip kerja dari mekanisme ini yaitu material akan masuk secara kontinu selama selang waktu tertentu dan tertampung pada dua buah plat yang berfungsi sebagai katup. Pada saat teeth dari roda gigi penggerak berkontak dengan roda gigi pada mekanisme yang akan digerakkan, maka akan terjadi gerakan membuka pada mekanisme dan material akan mengalir. Ketika roda gigi penggerak tidak lagi berkontak maka mekanisme pengumpanan material ini secara otomatis akan tertutup. Gerakan menutup pada mekanisme ini terjadi akibat gaya balik yang diberikan oleh pegas yang terdapat pada sistem ini, sehingga aliran material terhambat.

Selanjutnya dilakukan analisis kinematika dan dinamik dengan menggunakan metode bilangan kompleks sehingga persamaan posisi, kecepatan, percepatan, gaya inersia dan torsi masukan dapat diperoleh sehingga nantinya kita bisa mengetahui torsi dan kecepatan dari penggerak yang akan digunakan.

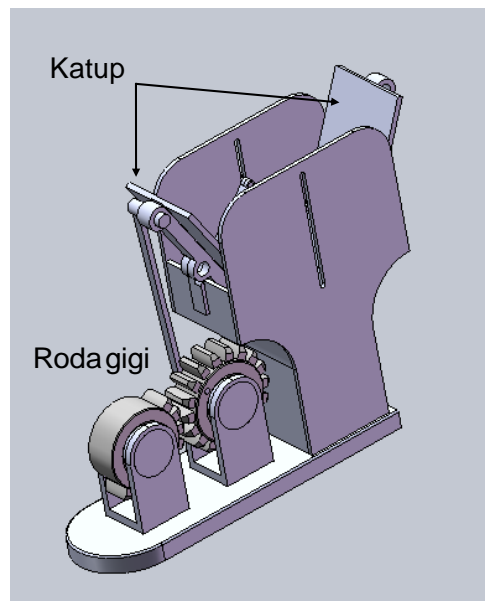

Gambar 3. Model CAD mekanisme pengumpanan material

Diagram kinematik sistem pengumpan material ini diperlihatkan pada Gambar 4. Pada diagram kinematik ini terlihat tiga bagian utama berupa mekanisme empat batang untuk mengatur bukaan katub, dyad yang digunakan untuk mentransmisikan gerakan bukaan katup dan sebuah sistem pegas untuk mengembalikan katub kekondisi awal setelah terjadi pembukaan.

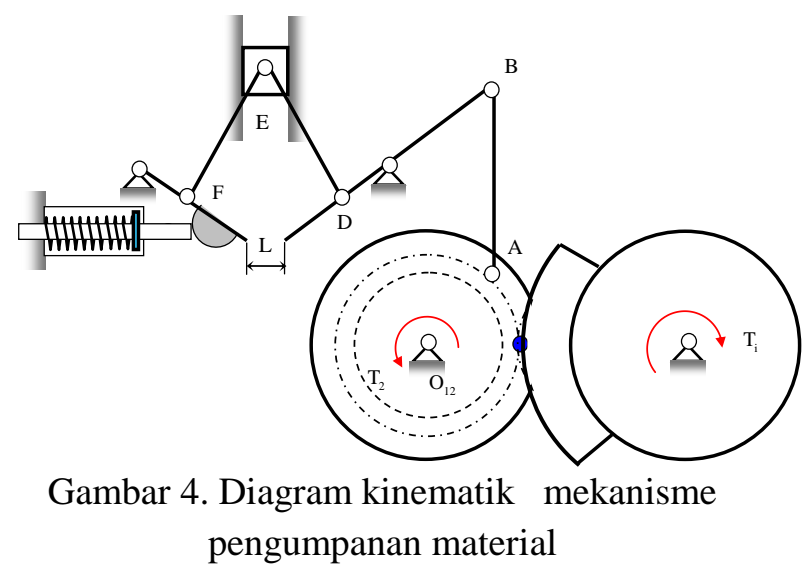

\subsection{Analisis Kinematik Mekanisme Pengumpanan Material}

Untuk kemudahan dalam melakukan analisis kinematik, pada Gambar 5 diperlihat loop vektor untuk mekanisme empat batang dan dyad penyusun mekanisme pengumpan material.

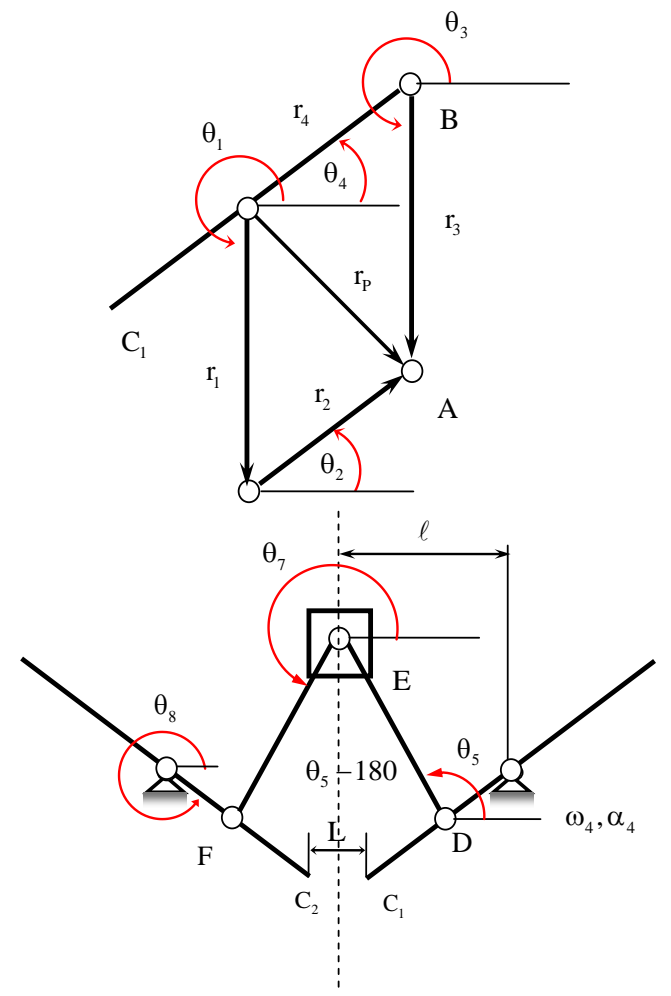

Gambar 5. Loop vektor dan perpindahan sudut Pada mekanisme ini, input diberikan pada batang 2 berupa sudut $\theta_{2}$ yang berubah terhadap waktu, 
kecepatan sudut $\dot{\theta}_{2}$, dan percepatan sudut tertentu $\ddot{\theta}_{2}$. Posisi sudut batang 2 , posisi ground dan panjang masing-masing batang sudah ditentukan terlebih dahulunya. Posisi batang lain pada mekanisme diperoleh dengan metoda bilangan kompleks melalui penurunan persamaan posisi, Penurunan persamaan posisi terhadap waktu diperoleh persamaan kecepatan, kemudian penurunan persamaan kecepatan terhadap waktu akan menghasilkan persamaan percepatan.

Hal yang pertama dilakukan yaitu menghitung perpindahan titik A terhadap tumpuan batang penghubung 4 dan dimensi dari sudut-sudut lainnya yang dapat dinyatakan dengan

$r_{p}=\sqrt{r_{1}^{2}-2 \cdot r_{1} \cdot r_{2} \sin \theta_{2}+r_{2}^{2}}$.

Selanjutnya dihitung sudut batang tiga dan batang empat dengan menggunakan persamaan (28)-(30)

$$
\begin{aligned}
& \theta_{\mathrm{p}}=\cos ^{-1}\left(\frac{\mathrm{r}_{1}^{2}+\mathrm{r}_{\mathrm{p}}{ }^{2}-\mathrm{r}_{2}^{2}}{2 \cdot \mathrm{r}_{1} \cdot \mathrm{r}_{\mathrm{p}}}\right) \\
& \beta=\cos ^{-1}\left(\frac{\mathrm{r}_{3}^{2}+\mathrm{r}_{4}{ }^{2}-\mathrm{r}_{\mathrm{p}}^{2}}{2 \cdot \mathrm{r}_{3} \cdot \mathrm{r}_{4}}\right) \\
& \delta=\cos ^{-1}\left(\frac{\mathrm{r}_{3}^{2}+\mathrm{r}_{\mathrm{p}}{ }^{2}-\mathrm{r}_{4}{ }^{2}}{2 \cdot r_{3} \cdot \mathrm{r}_{\mathrm{p}}}\right) \\
& \gamma=180-\beta-\delta \\
& \theta_{4}=\theta_{1}+\theta_{\mathrm{p}}+\gamma-360 \\
& \theta_{3}=180+\beta+\theta_{4}
\end{aligned}
$$

Persamaan kecepatan diperoleh dengan menurunkan persamaan posisi terhadap waktu, $t$ sehingga diperoleh kecepatan sudut batang penghubung 3 dan 4 , yang dinyatakan dengan

$$
\begin{gathered}
\omega_{3}=\frac{\omega_{2} \cdot r_{2} \sin \left(\theta_{2}-\theta_{4}\right)}{r_{3} \sin \left(\theta_{3}-\theta_{4}\right)} \\
\omega_{4}=\frac{\omega_{2} \cdot r_{2} \sin \left(\theta_{2}-\theta_{3}\right)}{r_{4} \sin \left(\theta_{4}-\theta_{3}\right)}
\end{gathered}
$$

Persamaan percepatan diperoleh dengan menurunkan persamaan kecepatan terhadap waktu $t$ sehingga menghasilkan :

$\alpha_{3}=\frac{\alpha_{2} \cdot r_{2} \sin \left(\theta_{2}-\theta_{4}\right)+\omega_{2}^{2} \cdot r_{2} \cos \left(\theta_{2}-\theta_{4}\right)-\omega_{3}^{2} \cdot r_{3} \cos \left(\theta_{3}-\theta_{4}\right)-\omega_{4}^{2} \cdot r_{4}}{\mathrm{r}_{3} \sin \left(\theta_{3}-\theta_{4}\right)}$ (32b)

$\alpha_{4}=\frac{\alpha_{2} \cdot r_{2} \sin \left(\theta_{2}-\theta_{3}\right)+\omega_{2}^{2} \cdot r_{2} \cos \left(\theta_{2}-\theta_{3}\right)-\omega_{3}^{2} \cdot r_{3}-\omega_{4}{ }^{2} \cdot r_{4} \cos \left(\theta_{4}-\theta_{3}\right)}{r_{4} \sin \left(\theta_{4}-\theta_{3}\right)}$ (32c)

Cara yang sama digunakan untuk menentukan posisi sudut, kecepatan dan percepatan sudut untuk batang 5,7 dan 8 , seperti yang dinyatakan dengan:

$$
\begin{aligned}
& \theta_{5}=\cos ^{-1}\left(\frac{\ell-\mathrm{r}_{\mathrm{D}} \cos \left(\theta_{4}+180\right)}{\mathrm{r}_{\mathrm{E} . \mathrm{D}}}\right) \\
& \theta_{7}=360^{0}-\theta_{5} \\
& \theta_{8}=360^{0}-\theta_{4} \\
& \omega_{5}=-\frac{\omega_{4} \cdot \mathrm{r}_{\mathrm{D} \cdot \mathrm{O} 4} \cos \theta_{3}}{\mathrm{r}_{\mathrm{ED}} \cos \theta_{5}} \\
& \dot{\mathrm{r}}_{\mathrm{E}}=\omega_{4} \cdot \mathrm{r}_{\mathrm{D}} \sin \theta_{4}+\omega_{5} \cdot \mathrm{r}_{\mathrm{DE}} \cdot \alpha_{5} \cos \theta_{5} \\
& \alpha_{5}=\frac{\mathrm{r}_{\mathrm{D}} \cdot \omega_{4}{ }^{2} \sin \left(180+\theta_{4}\right)-\mathrm{r}_{\mathrm{D}} \cdot \alpha_{4} \cos \left(180+\theta_{4}\right)+\mathrm{r}_{\mathrm{D}} \cdot \omega_{5}{ }^{2} \sin \theta_{5}}{\mathrm{r}_{\mathrm{DE}} \cdot \cos \theta_{5}}
\end{aligned}
$$

$$
\begin{aligned}
\ddot{\mathrm{r}}_{\mathrm{E}}= & -\mathrm{r}_{\mathrm{D}} \cdot \alpha_{4} \sin \left(180+\theta_{4}\right)-\mathrm{r}_{\mathrm{D}} \cdot \omega_{4}{ }^{2} \cos \left(180+\theta_{4}\right) \\
& -\mathrm{r}_{\mathrm{DE}} \cdot \alpha_{5} \sin \theta_{5}-\mathrm{r}_{\mathrm{D}} \cdot \omega_{5}{ }^{2} \cos \theta_{5}
\end{aligned}
$$

Karena batang 5 dan batang 7 mempunyai orientasi sudut dan panjang yang simetri, maka nominal kecepatan dan percepatan batang 7 akan sama dengan arah berlawanan dan hubungan yang sama terjadi pada batang 4 dan batang 8

\subsection{Analisis Dinamik Mekanisme Pengumpanan Material}

Pada pembahasan sebelumnya, metoda bilangan kompleks dapat dipergunakan untuk menentukan vektor posisi, kecepatan dan percepatan. Untuk analisis dinamika, metoda ini dapat juga dipergunakan untuk menentukan gaya-gaya inersia dan torsi masukan yang diperlukan untuk menggerakkan mekanisme. Persamaan dasar dari metode ini dapat dilihat pada pembahasan analisis kinematika sebelumnya. 
Pada mekanisme pengumpanan material ini, batang 2 merupakan batang input yang diberikan torsi dan putaran yang konstan. Gerakan batang 2 ini akan mengakibatkan batang batang 4 dan 8 bergerak menjauh, dimana kedua batang ini berfungsi sebagai katup, dan ketika kedua roda gigi tidak lagi berkontak, mekanisme katup secara otomatis menutupnya dimana gaya menutup ini dihasilkan oleh pegas.

Sebelum analisa dinamik dilakukan, terlebih dahulu dihitung percepatan pusat masa untuk tiaptiap batang penghubung. Lokasi pusat massa msing-masing batang berada ditengah-tengah batang seperti diilustrasikan pada Gambar 6 .

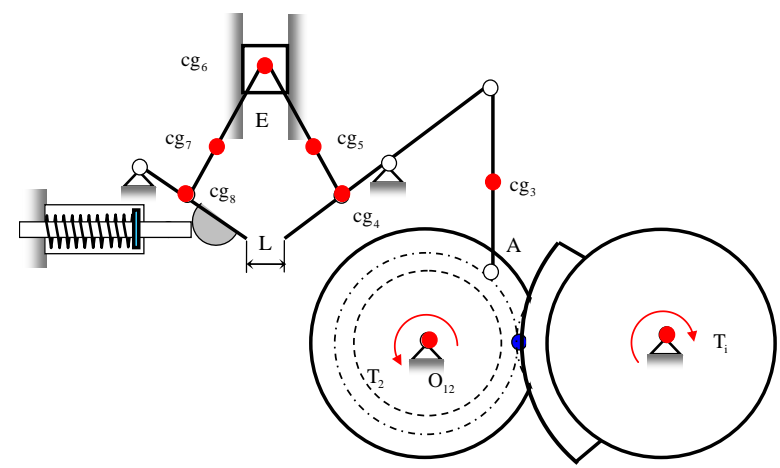

Gambar 6. Titik-titik pusat massa dan lokasi penempatan pegas

Percepatan masing-masing batang dapat dinyatakan dengan persamaan (40)-(50)

$\theta_{\mathrm{A}_{\mathrm{g} 3}}=\tan ^{-1}\left(\frac{\operatorname{Im}\left(\mathrm{A}_{\mathrm{g} 3}\right)}{\operatorname{Re}\left(\mathrm{A}_{\mathrm{g} 3}\right)}\right)$

$\mathrm{A}_{\mathrm{g} 3}=\sqrt{\left(\operatorname{Im}\left(\mathrm{A}_{\mathrm{g} 3}\right)\right)^{2}+\left(\operatorname{Re}\left(\mathrm{A}_{\mathrm{g} 3}\right)\right)^{2}}$

$\theta_{\mathrm{A}_{\mathrm{g} 4}}=\tan ^{-1}\left(\frac{\operatorname{Im}\left(\mathrm{A}_{\mathrm{g} 4}\right)}{\operatorname{Re}\left(\mathrm{A}_{\mathrm{g} 4}\right)}\right)$

$\mathrm{A}_{\mathrm{g} 4}=\sqrt{\left(\operatorname{Im}\left(\mathrm{A}_{\mathrm{g} 4}\right)\right)^{2}+\left(\operatorname{Re}\left(\mathrm{A}_{\mathrm{g} 4}\right)\right)^{2}}$

$\theta_{\mathrm{A}_{\mathrm{g} 5}}=\tan ^{-1}\left(\frac{\operatorname{Im}\left(\mathrm{A}_{\mathrm{g} 5}\right)}{\operatorname{Re}(\mathrm{Ag} 5)}\right)$

$\mathrm{A}_{\mathrm{g} 5}=\sqrt{(\operatorname{Re}(\mathrm{Ag} 5))^{2}+\left(\operatorname{Im}\left(\mathrm{A}_{\mathrm{g} 5}\right)\right)^{2}}$
$\theta_{\mathrm{A}_{\mathrm{g}}}=\tan ^{-1}\left(\frac{\operatorname{Im}(\mathrm{Ag} 7)}{\operatorname{Re}(\operatorname{Ag} 7)}\right)$

$A_{g 7}=\sqrt{(\operatorname{Re}(\operatorname{Ag} 7))^{2}+(\operatorname{Im}(\operatorname{Ag} 7))^{2}}$

$\theta_{\mathrm{A}_{\mathrm{g} 8}}=\tan ^{-1}\left(\frac{\operatorname{Im}\left(\mathrm{A}_{\mathrm{g} 8}\right)}{\operatorname{Re}\left(\mathrm{A}_{\mathrm{g} 8}\right)}\right)$

$\mathrm{A}_{\mathrm{g} 8}=\sqrt{\left(\operatorname{Im}\left(\mathrm{A}_{\mathrm{g} 8}\right)\right)^{2}+\left(\operatorname{Re}\left(\mathrm{A}_{\mathrm{g} 8}\right)\right)^{2}}$

Selanjutnya gaya yang bekerja pada pegas dapat dihitung berdasarkan diagram benda bebas batang 8 seperti diperlihatkan pada Gambar 7. Gaya ini selalu mempunyai jarak yang konstan terhadap tumpuan. Besar gaya tersebut dapat dinyatakan dengan persamaan (51).



Gambar 7. Diagram benda bebas batang 8

$\sum \mathrm{M}_{\mathrm{O} 8}=0$

$\mathrm{F}_{78}{ }^{\mathrm{T}}=\frac{\mathrm{F}_{\mathrm{p}} \cdot \mathrm{r}_{\mathrm{p}}+\mathrm{m}_{8} \mathrm{~A}_{8} \cdot \mathrm{r}_{\mathrm{OF}} \cdot \sin \left(\theta_{8}-\theta_{\mathrm{A}_{83}}\right)}{\overline{\mathrm{O}_{18} \cdot \mathrm{O}_{78}}}$

Gaya $\mathrm{F}_{87}{ }^{\mathrm{T}}$ membentuk sudut $\vartheta$ dimana besarnya yaitu :

$\vartheta=\theta_{7}-\theta_{8}-\frac{\pi}{2}$

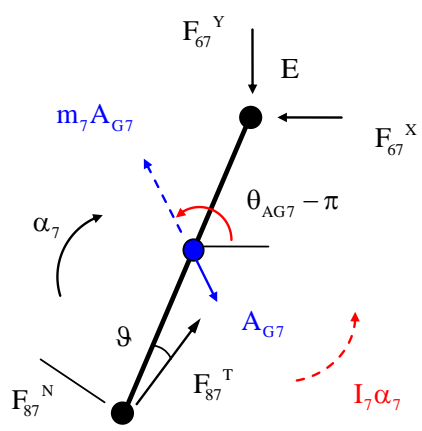

Gambar 8. Diagram benda bebas batang 7 
Selanjutnya dianalisis batang 7 pada batang ini dengan menggunakan asumsi bahwa Arah gaya $\mathrm{F}_{87}{ }^{\mathrm{N}}$ searah jarum jam terhadap titik referensi $\mathrm{O}_{67}$ dan arah gaya $\mathrm{F}_{67}^{\mathrm{Y}}$ ke bawah dan arah $\mathrm{F}_{67}{ }^{\mathrm{X}}$ ke kiri.

$\sum \mathrm{M}_{\mathrm{E}}=0$

$\mathrm{F}_{87}{ }^{\mathrm{N}}=\frac{\mathrm{F}_{87}{ }^{\mathrm{T}} \cdot \mathrm{r}_{7} \sin \vartheta+\mathrm{I}_{\mathrm{G} 7} \alpha_{7}-\mathrm{m}_{7} \mathrm{~A}_{\mathrm{g} 7} \sin \left(\theta_{\mathrm{Ag} 7}-\theta_{7}\right)}{\mathrm{r}_{7} \cos \vartheta}$

$\sum \mathrm{F}_{\mathrm{x}}=0$

$\mathrm{F}_{67}{ }^{\mathrm{x}}=\mathrm{F}_{87}{ }^{\mathrm{T}} \cdot \cos \left(\theta_{8}-\frac{\pi}{2}\right)-\mathrm{F}_{87}{ }^{\mathrm{N}} \cdot \cos \left(\pi-\theta_{8}\right)-\mathrm{m}_{7} \mathrm{~A}_{\mathrm{g} 7} \cos \left(\theta_{\mathrm{Ag} 7}+\pi\right)$

$\sum \mathrm{F}_{\mathrm{Y}}=0$

$\mathrm{F}_{67}{ }^{\mathrm{Y}}=\mathrm{F}_{87}{ }^{\mathrm{T}} \cdot \sin \left(\theta_{8}-\frac{\pi}{2}\right)-\mathrm{F}_{87}{ }^{\mathrm{N}} \cdot \cos \left(\pi-\theta_{8}\right)-\mathrm{m}_{7} \mathrm{~A}_{\mathrm{g} 7} \sin \left(\theta_{\mathrm{Ag} 7}+\pi\right)$

Selanjutnya gaya yang bekerja pada batang 5 dan batang 6 dihitung berdasarkan diagram benda bebas seperti diperlihatkan pada Gambar 9.

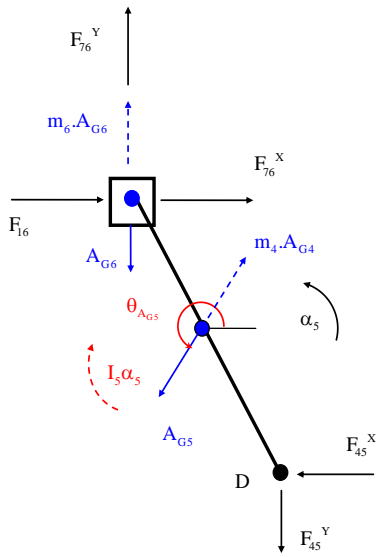

Gambar 9. Diagram benda bebas batang 5 dan 6

Untuk melakukan analisis dinamik pada batang 6 dilakukan dengan merujuk kepada hasil yang diperoleh pada analisis pada bantang 5 dan 6 yang menghasilkan persamaan berikut:

$\sum \mathrm{M}_{\mathrm{D}}=0$

$\mathrm{F}_{16}=\frac{-\mathrm{F}_{76}{ }^{x} \cdot \mathrm{r}_{5} \sin \theta_{5}-\mathrm{m}_{5} \mathrm{~A}_{\mathrm{g} 5} \sin \left(\theta_{\mathrm{Ag} 5}+\pi\right) \cdot \overrightarrow{\mathrm{D} \cdot \mathrm{A}_{\mathrm{G} 5}} \sin \left(\theta_{5}\right)-\mathrm{I}_{\mathrm{G} 5} \alpha_{5}}{\mathrm{r}_{5} \sin \theta_{5}}$

$\sum \mathrm{F}_{\mathrm{x}}=0$

$\mathrm{F}_{45}{ }^{\mathrm{x}}=\mathrm{F}_{16}+\mathrm{F}_{76}{ }^{\mathrm{x}}+\mathrm{m}_{5} \mathrm{~A}_{\mathrm{g} 5} \cos \left(\theta_{\mathrm{Ag} 5}+\pi\right)$ $\sum \mathrm{F}_{\mathrm{y}}=0$

$\mathrm{F}_{45}{ }^{\mathrm{y}}=\mathrm{F}_{76}{ }^{\mathrm{y}}+\mathrm{m}_{5} \mathrm{~A}_{\mathrm{g} 5} \sin \left(\theta_{\mathrm{Ag} 5}+\pi\right)+\mathrm{m}_{6} \mathrm{~A}_{\mathrm{g} 6}$

Selanjutnya analisis pada dilakukan berdasarkan diagram benda bebas yang diberikan pada gambar 10. Dengan menerapkan persamaan keseimbangan momen diperoleh

$\sum \mathrm{M}_{\mathrm{O} 14}=0$

$\mathrm{F}_{34}{ }^{\mathrm{T}}=\frac{\mathrm{F}_{54}{ }^{\mathrm{y}} \cdot \mathrm{r}_{14 . \mathrm{D}} \cos \theta_{4}-\mathrm{F}_{54}{ }^{\mathrm{x}} \cdot \mathrm{r}_{14 . \mathrm{D}} \sin \theta_{4}-\mathrm{m}_{3} \mathrm{~A}_{\mathrm{g} 3} \sin \left(\theta_{8}-\theta_{4}-180\right)}{\mathrm{r}_{14 . \mathrm{B}}}$

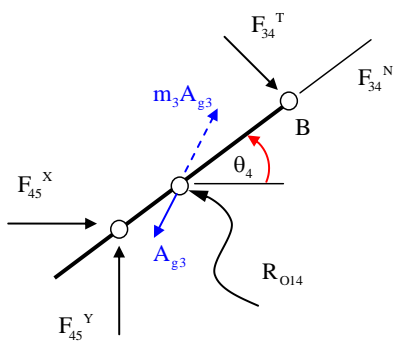

Gambar 10. Diagram benda bebas batang 4

Konfigurasi gaya-gaya yang bekerja pada batang 3 diperlihatkan pada gambar 11. Dengan menggunakan keseimbangan momen di titik A diperoleh hubungan berikut:

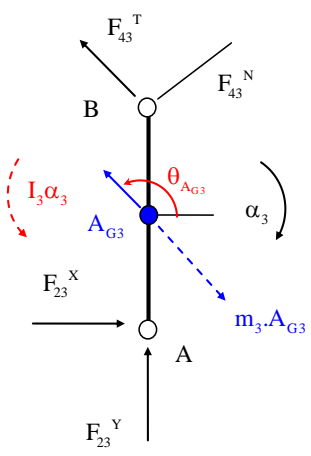

Gambar 11. Diagram benda bebas batang 3

$\sum \mathrm{M}_{\mathrm{A}}=0$

$\mathrm{F}_{34}{ }^{\mathrm{N}}=\frac{\mathrm{F}_{43}{ }^{\mathrm{T}} \mathrm{r}_{3} \sin \left(\theta_{3}-\theta_{4}\right)+\mathrm{m}_{3} \mathrm{~A}_{\mathrm{g} 3} \cdot \mathrm{r}_{\mathrm{Ag} 3 \mathrm{~A}} \sin \left(\theta_{\mathrm{Ag} 3}-\theta_{3}\right)+\mathrm{I}_{\mathrm{G} 3} \alpha_{3}}{\mathrm{r}_{3} \cos \left(\theta_{3}-\theta_{4}\right)}$

$\sum \mathrm{F}_{\mathrm{x}}=0$

$\mathrm{F}_{23}{ }^{\mathrm{x}}=-\mathrm{F}_{34}{ }^{\mathrm{N}} \cos \theta_{4}-\mathrm{F}_{34}{ }^{\mathrm{T}} \sin \theta_{4}-\mathrm{m}_{3} \mathrm{~A}_{\mathrm{g} 3} \cos \theta_{\mathrm{Ag} 3}$

$\sum \mathrm{F}_{\mathrm{y}}=0$

$\mathrm{F}_{23}{ }^{\mathrm{Y}}=\mathrm{m}_{3} \mathrm{~A}_{\mathrm{g} 3} \sin \theta_{\mathrm{Ag} 3}+\mathrm{F}_{34}{ }^{\mathrm{N}} \sin \theta_{4}+\mathrm{F}_{34}{ }^{\mathrm{T}} \cos \theta_{4}$ 
Pengaruh gaya luar dan torsi pada batang input diperlihatkan pada Gambar 12. Hubungan gayagaya tersebut dapat dinyatakan dengan menghitung keseimbangan statik pada titik $\mathrm{O}_{12}$

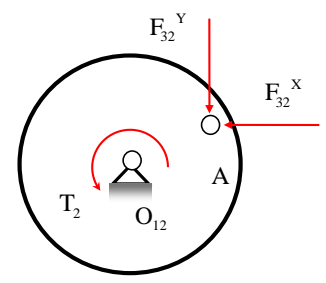

Gambar 12. Diagram benda bebas batang 2

$\sum \mathrm{M}_{\mathrm{O} 2}=0$

$\mathrm{T}_{2}=\mathrm{F}_{32}{ }^{\mathrm{y}} \cdot \mathrm{r}_{2} \cos \theta_{2}-\mathrm{F}_{32}{ }^{\mathrm{x}} \cdot \mathrm{r}_{2} \sin \theta_{2}$

Setelah diperoleh nilai torsi yang diterapkan pada batang 2, maka torsi input dari dari roda gigi penggerak dapat diketahui. Hal ini dihitung berdasarkan perbandingan jari-jari kedua buah roda gigi yang berkontak seperti diperlihatkan pada Gambar 12.

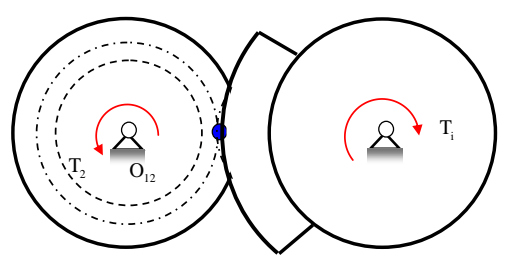

Gambar 13. Kontak antara roda gigi penggerak dengan batang penghubung 2

$$
\mathrm{T}_{\mathrm{i}}=-\mathrm{T}_{2} \frac{\mathrm{r}_{2}}{\mathrm{r}_{\mathrm{i}}}
$$

Jika roda gigi penggerak berputar dengan kecepatan putar $\omega_{i}$, maka daya input dari roda gigi penggerak bisa diketahui, dimana:

$$
\mathrm{P}_{\mathrm{i}}=\mathrm{T}_{\mathrm{i}} \cdot \omega_{\mathrm{i}}
$$

\section{HASIL DAN PEMBAHASAN}

Pada bab ini diberikan hasil analisis studi kasus mekanisme pengumpanan material dengan berbagai variasi perbandingan panjang batang (kinematik konstan) dan posisi tumpuan pada mekanisme. Pemberian variasi pada panjang batang dan posisi tumpuan tersebut bertujuan untuk mendapatkan torsi minimum yang dibutuhkan untuk menggerakkan mekanisme. Analisis awal dilakukan pada komponen elemen pendukung yaitu pegas dalam rangkaian penggerak pada kinematik konstan sehingga kostanta kekakuan dari pegas dapat diketahui.

\subsection{Desain Pegas}

Dalam perancangan konstanta kekakuan pegas ini, ditentukan beban maksimum yang mampu ditahan oleh mekanisme. Beban maksimum yang mampu ditampung oleh mekanisme berupa gaya yang dihasilkan oleh matreial feeding dalam hal ini sebesar 2500 N. Agar katup pada mekanisme ini selalu tertutup pada saat tidak terjadi kontak dengan roda gigi penggerak, maka harus diberikan gaya dalam pada pegas dengan cara ditekan. Jadi pada saat mekanisme menahan beban sampai pada kondisi beban maksimum dari material, katup selalu dalam keadaan tertutup. Perancangan kekakuan pegas ini akan menentukan besar torsi yang dibutuhkan untuk menggerakkan mekanisme. Gambar katup pada mekanisme dengan sistem pegasnya dapat dilihat pada Gambar 14.

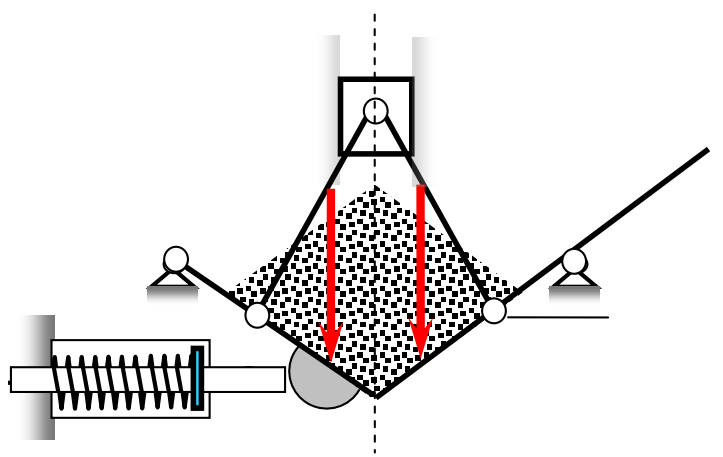

Gambar 14. Penempatan sistem pegas pada mekanisme pengumpanan material

Berdasarkan perhitungan yang dilakukan diperoleh besar konstanta kekakuan pegas $23,180 \mathrm{kN} / \mathrm{m}$ dan pegas tertekan sepanjang $0,1 \mathrm{~m}$ pada saat tumpukan material akan saat akan diumpankan. Jika berat material melebihi dari beban maksimumnya, maka katup akan terbuka tidak pada waktunya. Hal ini dikarena beban material melebihi gaya dalam yang diberikan pada pegas. Proses pemberian beban melebihi dari kapasitas ini harus dihindari supaya siklus dari mekanisme ini dapat berjalan dengan lancar. 


\subsection{Perancangan Kinematik Konstan}

Dimensi konstanta kinematik penyusun mekanisme pengumpanan material terkait dengan unjuk kerja akan didiskusikan pada bagian ini. Pada mekanisme pengumpanan material ini, sistem disusun dari dua buah mekanisme empat batang. Data geometri mekanisme tersebut dapat dilihat pada Tabel 1. yang mewakili konstanta-konstanta yang diilustrasikan pada Gambar 3 dan 5.

Tabel 1 Data dimensi dan berat masing-masing komponen mekanik mekanisme pengumpanan material

\begin{tabular}{||c||l|c||c|}
\hline No & Parameter Kinematik & Ukuran & Satuan \\
\hline \hline 1 & Panjang batang 1 & 1 & $\mathrm{~m}$ \\
\hline \hline 2 & Panjang batang 2 & 0,5 & $\mathrm{~m}$ \\
\hline \hline 3 & Panjang batang 3 & 1 & $\mathrm{~m}$ \\
\hline 4 & Panjang batang 4 & 1 & $\mathrm{~m}$ \\
\hline 5 & Panjang batang 5 & 1 & $\mathrm{~m}$ \\
\hline 6 & Panjang batang 7 & 1 & $\mathrm{~m}$ \\
\hline 7 & Panjang batang 8 & 0,5 & $\mathrm{~m}$ \\
\hline \hline 8 & Jarak joint D ke O14 & 0,5 & $\mathrm{~m}$ \\
\hline 9 & Jarak joint F ke O18 & 0,5 & $\mathrm{~m}$ \\
\hline \hline 10 & Massa batang 3 & 8 & $\mathrm{~kg}$ \\
\hline \hline 11 & Massa batang 4 & 50 & $\mathrm{~kg}$ \\
\hline \hline 12 & Massa batang 5 & 5 & $\mathrm{~kg}$ \\
\hline 13 & Massa batang 6 & 1 & $\mathrm{~kg}$ \\
\hline \hline 14 & Massa batang 7 & 5 & $\mathrm{~kg}$ \\
\hline 15 & Massa batang 8 & 45 & $\mathrm{~kg}$ \\
\hline \hline 16 & Inersia Gravity batang 3 & 1,5 & $\mathrm{~kg}-\mathrm{m}^{\wedge} 2$ \\
\hline \hline 17 & Inersia Gravity batang 4 & 12 & $\mathrm{~kg}-\mathrm{m}^{\wedge} 2$ \\
\hline \hline 18 & Inersia Gravity batang 5 & 1,2 & $\mathrm{~kg}-\mathrm{m}^{\wedge} 2$ \\
\hline \hline 19 & Inersia Gravity batang 7 & 1,2 & $\mathrm{~kg}-\mathrm{m}^{\wedge} 2$ \\
\hline \hline 20 & Inersia Gravity batang 8 & 11 & $\mathrm{~kg}-\mathrm{m}^{\wedge} 2$ \\
\hline 21 & Massa jenis material & 100 & $\mathrm{~kg} / \mathrm{m}^{\wedge} 3$ \\
\hline \hline
\end{tabular}

Mekanisme digerakkan oleh sebuah roda gigi penggerak dengan putaran dan daya tertentu. Pada saat mekanisme tidak berkontak dengan roda gigi penggerak, material yang dialirkan melalui belt akan masuk secara kontinu dan tertampung pada dua buah plat yang berfungsi sebagai katup. Dan pada saat terjadi kontak antara roda gigi penggerak dengan roda gigi yang digerakkan, maka akan terjadi gerakan membuka pada mekanisme pengumpanan material dan material akan mengalir.

Input mekanisme berupa persentase bukaan katup, debit aliran, lama bukaan katup, dan lama katup tertutup. Lama waktu bukaan dan katup tertutup untuk satu kali siklus putaran ini akan mempengaruhi kecepatan sudut dari roda gigi penggerak. Putaran dari roda gigi penggerak ini juga harus disesuaikan dengan debit aliran material yang ditampung oleh mekanisme. Jika diketahui waktu katup tertutup selama 10 detik dan massa jenis dari material yang akan dialirkan sebesar 100 $\mathrm{kg} / \mathrm{m}^{3}$, maka debit aliran maksimum dari material yang masuk ke mekanisme sebesar $0,25 \mathrm{~m}^{3} / \mathrm{s}$. Jika melebihi dari debit tersebut, maka pegas akan mulai terdefleksi dan katup akan terbuka karena melebihi dari beban maksimum yang mampu ditahan oleh mekanisme. Akibatnya material akan mengalir tidak pada waktunya dan hal ini akan mengganggu proses dari mekanisme ini.

Pada mekanisme ini, besar bukaan katup ditentukan, dimana batang 4 dan 8 yang berfungsi sebagai katup membentuk sudut $40^{\circ}$ ketika katup dalam keadaan tertutup dan $80^{\circ}$ ketika katup terbuka maksimum. Ketika dalam keadaan terbuka maksimum mekanisme akan membuka sebesar $1,01 \mathrm{~m}$

Pada saat mekanisme dalam keadaan terbuka maksimum, pegas akan memberikan gaya sebesar 3615,40 N. Pada Gambar 15 diperlihatkan grafik gaya pegas terhadap perubahan sudut input. Dimana disini yang bertindak sebagai sudut input yaitu posisi batang penghubung 2 .

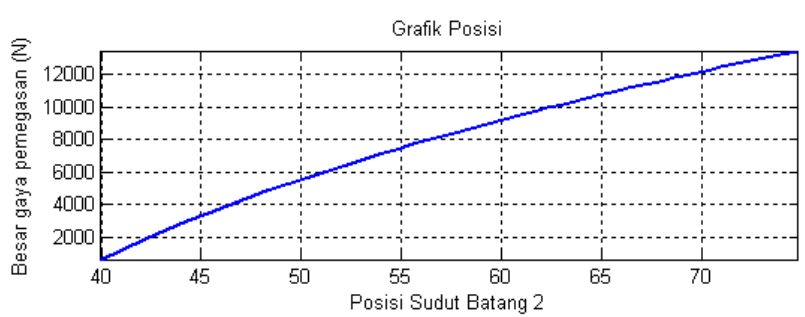

Gambar 15. Nilai gaya pemegasan terhadap perubahan sudut batang 2

Pada kasus ini, ditetapkan suatu dimensi dari mekanisme pengumpanan material untuk dijadikan referensi. Selanjutnya dilakukan simulasi sudut input untuk melihat pengaruh perubahan nilai torsi dari penggerak terhadap perubahan dimensi dari batang penghubung. Mekanisme ini disimulasikan pada debit aliran maksimum yaitu $0,25 \mathrm{~m}^{3} / \mathrm{s}$ dan waktu untuk katup tertutup dan terbuka untuk satu siklus selama 15 detik dan kecepatan putar dari roda gigi penggerak diperoleh $4 \mathrm{rpm}$. Analisis ini bertujuan untuk melihat pengaruh kecepatan putaran motor input terhadap torsi untuk menggerakkan mekanisme. Kemudian hasil dari berbagai variasi yang dibuat, dibandingkan dengan hasil yang didapat pada parameter awal. 
Berdasarkan kinematik konstan pada Tabel 1, diperoleh Torsi pada roda gigi penggerak sebesar 2705,74 N.m. Dari nilai torsi yang didapat diketahui besar daya penggerak dari roda gigi penggerak yaitu 1133,16 watt. Dimana besar daya dihitung dengan mengalikan torsi dan kecepatan putar. Sebagai contoh pada Gambar 16 ditampilkan grafik posisi sudut batang penghubung 2 terhadap torsi pada roda gigi penggerak. Dari Gambar 16 terlihat pengaruh posisi sudut batang 2 terhadap torsi. Torsi bernilai minimum saat katup material akan dibuka.

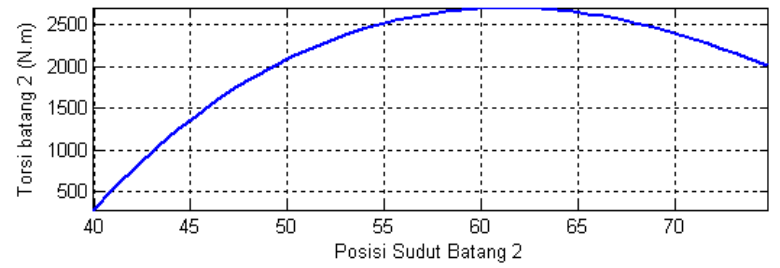

Gambar 16. Nilai torsi terhadap perubahan sudut batang 2 untuk variasi yang dijadikan referensi perbandingan

Untuk melihat pengaruh perubahan nilai torsi, harus dikaji beberapa variasi konstanta kinematik mekanisme ini. Tetapi konstrain berupa keparalelan harus dijaga. Perubahan sudut untuk batang penghubung 4 harus sama dengan perubahan sudut pada roda gigi penggerak.

\subsection{Evaluasi Unjuk Kerja Mekanisme}

Untuk menghasilkan mekanisme dengan unjuk kerja yang baik dilakukan evaluasi mekanisme dengan berbagai konfigurasi.

\subsubsection{Variasi Sudut Input (teta 1)}

Variasi pertama yang dilakukan adalah perubahan posisi tumpuan pada batang penghubung 2 terhadap tumpuan batang penghubung 4. Dimana parameter untuk posisi ini dinamakan teta 1 (lihat pada Gambar 17). Teta 1 divariasikan pada $285^{\circ}$ dan $300^{\circ}$. Hasil yang diperoleh dibandingkan dengan nilai torsi yang diperoleh dari mekanisme pada parameter awal. Grafik nilai torsi terhadap sudut batang penghubung 2 pada ketiga variasi ini dapat dilihat pada Gambar 18, Gambar 19 dan Gambar 20.

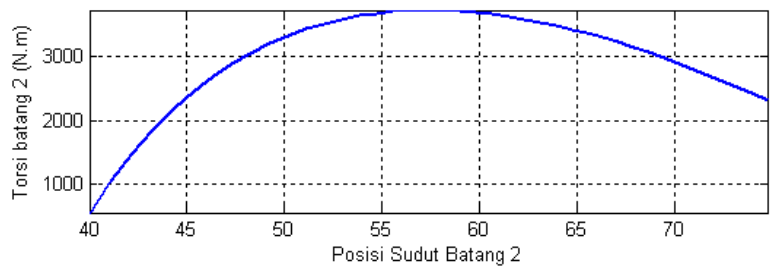

Gambar 17. Nilai torsi terhadap perubahan sudut batang 2 untuk variasi sudut teta $1\left(285^{\circ}\right)$

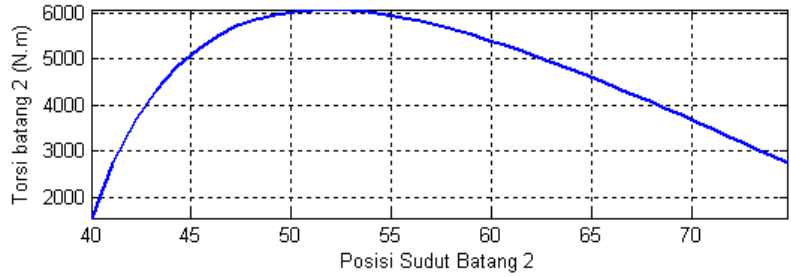

Gambar 18. Nilai torsi terhadap perubahan sudut batang 2 untuk variasi sudut teta $1\left(300^{\circ}\right)$

Untuk sudut teta $1\left(285^{\circ}\right)$ torsi maksimum sama dengan mekanisme referensi yaitu 3725,68 N.m. Dan untuk sudut teta $1\left(300^{\circ}\right)$ torsi maksimum yang didapat sebesar 6068,94 N.m. Dari ketiga variasi dari sudut teta 1 , dapat dilihat bahwa semakin besar sudut teta 1 yang terbentuk, torsi dari input juga akan semakin besar. Jadi, besar sudut teta 1 yang efektif adalah $270^{\circ}$.

\subsubsection{Variasi Panjang Batang 1 dan 3}

Variasi kedua yang dilakukan adalah perubahan panjang batang hubung 3 dan jarak tumpuan 1 dan 2. Panjang kedua parameter ini harus sama panjang untuk menjamin mekanisme bergerak secara paralel. Panjang parameter divariasikan dengan panjang 1,5 dan 2 satuan. Hasil yang diperoleh dibandingkan dengan nilai torsi yang diperoleh dengan nilai torsi pada mekanisme referensi. Grafik nilai torsi terhadap sudut batang penghubung 2 pada variasi ini dapat dilihat pada Gambar 4.6 dan Gambar 4.7.

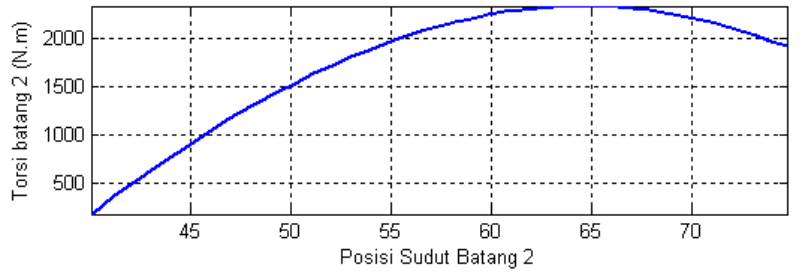

Gambar 19. Nilai torsi terhadap perubahan sudut batang 2 untuk variasi panjang batang 1 dan 3 (1.5 satuan)

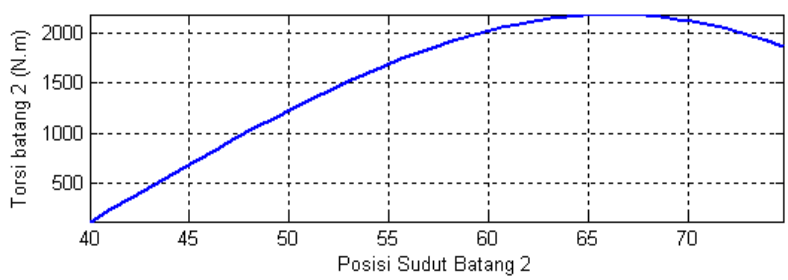

Gambar 20. Nilai torsi terhadap perubahan sudut batang 2 untuk variasi panjang batang 1 dan 3 ( 2 satuan)

Untuk panjang batang hubung 1 dan 3 (1,5 satuan), torsi maksimum 2335,09 N.m. sedangkan untuk pemvariasian dengan panjang 2 satuan, torsi maksimum 2183,49 N.m. Dari variasi ini, dapat dilihat bahwa semakin besar panjang batang 
penghubung 1 dan 3 , torsi dari input juga akan semakin kecil.

\subsubsection{Variasi Jarak Joint $F$ dan D Terhadap Tumpuan}

Variasi ketiga yang dilakukan adalah jarak join $\mathrm{f}$ dan $\mathrm{d}$ terhadap tumpuan. Panjang parameter divariasikan dengan panjang 0,75 dan 0,25 satuan. Kemudian hasil yang diperoleh dibandingkan nilai torsi yang diperoleh dengan nilai torsi pada mekanisme referensi. Grafik nilai torsi terhadap sudut batang penghubung 2 pada variasi ini dapat dilihat pada Gambar 21 dan 22.

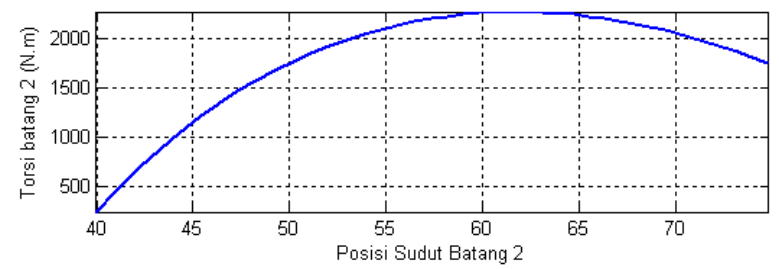

Gambar 21. Nilai torsi terhadap perubahan jarak joint $\mathrm{F}$ dan $\mathrm{D}$ terhadap tumpuan $(0,25$ satuan $)$

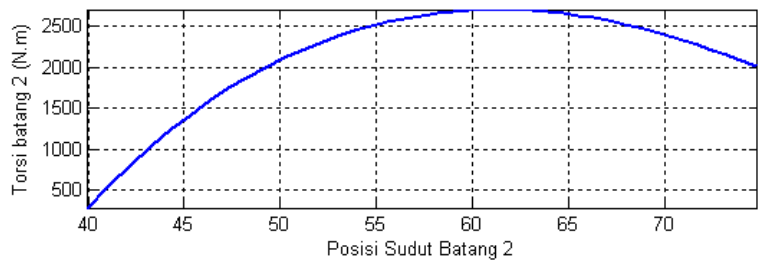

Gambar 22. Nilai torsi terhadap perubahan jarak join $\mathrm{F}$ dan $\mathrm{D}$ terhadap tumpuan $(0,75$ satuan $)$

Untuk variasi jarak titik D dan $\mathrm{F}$ terhadap tumpuan 0,25 satuan, torsi maksimum 2264,11 N.m. Sedangkan untuk variasi jarak titik $D$ dan $F$ terhadap tumpuan 0,75 satuan, torsi maksimum 2705,71 N.m. Dari variasi ini, dapat dilihat bahwa jarak titik $D$ dan $F$ terhadap tumpuan juga mempengaruhi besar torsi yang dihasilkan. Untuk variasi ini, jarak tumpuan yang efektif yaitu sebesar 0,25 satuan panjang.

\subsubsection{Variasi Panjang Batang 5 dan 7}

Variasi terakhir yang dilakukan adalah panjang batang 5 dan 7 . Panjang parameter divariasikan dengan panjang 1,5 dan 2 satuan. Kemudian hasil yang diperoleh dibandingkan nilai torsi yang diperoleh dengan nilai torsi pada mekanisme referensi. Grafik nilai torsi terhadap sudut batang penghubung 2 pada variasi ini dapat dilihat pada Gambar 23 dan 24.

Untuk variasi panjang batang 5 dan $7 \quad(0,75$ satuan), torsi maksimum 2099,48 N.m. Sedangkan Variasi panjang batang 5 dan 7 (1,5 satuan), torsi maksimum 3474,58 N.m. Berdarkan variasi ini, dapat dilihat bahwa panjang batang 5 dan 7 yang efektif yaitu 0,75 satuan panjang. Tapi jika panjang batang 5 dan 7 lebih kecil dari 0,75 satuan, katup dari mekanisme tidak bisa mencapai bukaan maksimum. Hal ini disebabkan karena panjang dari batang penghubung 5 dan 7 tidak mencukupi untuk bukaan katup maksimum.

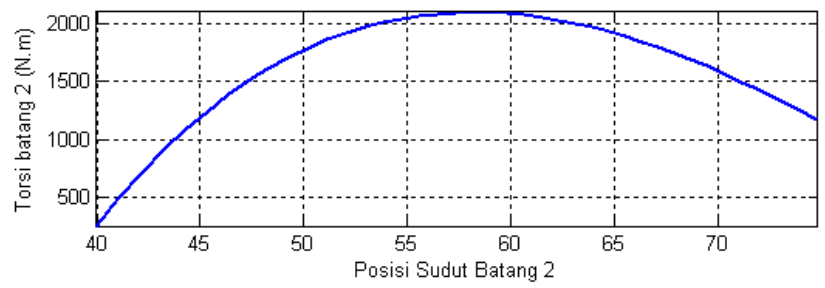

Gambar 23. Nilai torsi terhadap perubahan sudut batang 2 untuk variasi panjang batang 5 dan 7 (0,75 satuan)

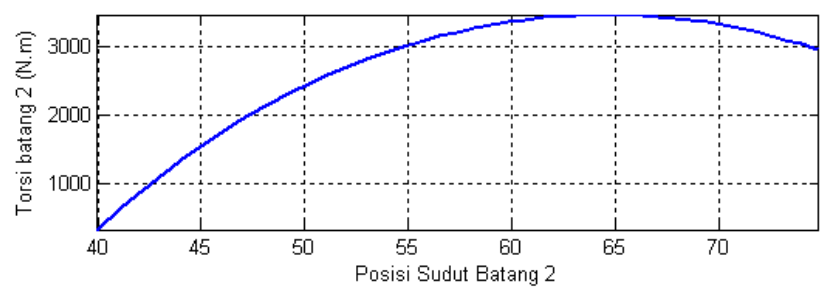

Gambar 24. Nilai torsi terhadap perubahan sudut batang 2 untuk variasi panjang batang 5 dan 7 (1,5 satuan)

\subsection{Pembahasan}

Dari variasi di atas, dilakukan kombinasi sehingga diperoleh nilai torsi minimum sebesar 1083,09 N.m. Grafik nilai torsi terhadap sudut batang penghubung 2 pada variasi ini dapat dilihat pada Gambar 25. Parameter untuk mekanisme yang optimal dari beberapa kali percobaan dapat dilihat pada Tabel 2.

Tabel 2 Konstanta kinematik yang optimal mekanisme pengumpan material

\begin{tabular}{||c||c||c||c||}
\hline \hline No. & Parameter Kinematik & Ukuran & Satuan \\
\hline \hline 1 & Sudut tetta 1 & 270 & Derajat \\
\hline \hline 2 & Panjang batang 1 dan 3 & 2 & panjang \\
\hline \hline 3 & Panjang batang 2 dan 4 & 1 & panjang \\
\hline \hline 4 & Panjang batang 5 dan 7 & 0,75 & panjang \\
\hline \hline 5 & Jarak joint D ke O14 & 0,25 & panjang \\
\hline
\end{tabular}

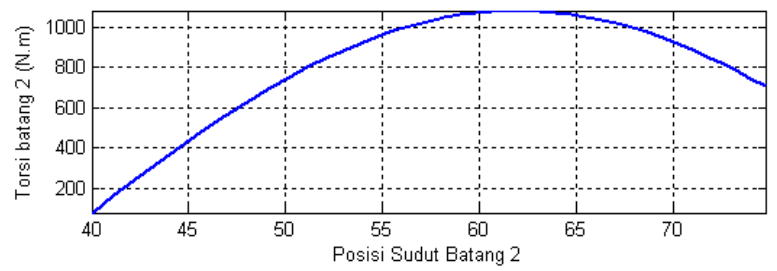

Gambar 25. Nilai torsi terhadap perubahan sudut batang 2 untuk parameter optimal 
Dari beberapa percobaan variasi yang dilakukan di atas dapat diketahui bahwa sudut yang dibentuk oleh batang 5 dan 7 sangat mempengaruhi nilai torsi input. Semakin besar sudut yang dibentuk batang 5 dan 7, maka torsi input yang dibutuhkan untuk menggerakkan mekanisme semakin besar. Hal ini dikarenakan besar momen yang dihasilkan. mekanisme kombinasi yang optimal dari beberapa percobaan.

Hal kedua yang mempengaruhi nilai torsi input yang dibutuhkan yaitu jarak titik $\mathrm{f}$ dan $\mathrm{d}$ terhadap tumpuan. Jarak titik $f$ dan $d$ ini nantinya juga akan mempengaruhi sudut kontak batang 5 dan 7 terhadap tumpuan slider. Jika jarak titik $\mathrm{f}$ dan $\mathrm{d}$ jauh terhadap tumpuan, maka sudut kontak batang 5 terhadap tumpuan akan semakin kecil sehingga torsi input yang dibutuhkan bertambah besar.

Hal selanjutnya yang mempengaruhi nilai torsi input yaitu rasio panjang batang hubung terhadap batang input. Semakin besar rasio tersebut maka torsi yang dibutuhkan semakin besar.

\section{KESIMPULAN}

Dari hasil analisis dan sintesis terhadap mekanisme empat batang untuk aplikasi pengumpanan material dimana mekanisme dirancang untuk berat material yang diumpankan sebesar $250 \mathrm{~kg}$. Dari hasil kalkulasi diperoleh dimensi konstanta kinematik untuk mekanisme empat batang dan dyad. Untuk mekanisme empat batang diperoleh panjang crank, coupler dan follower yaitu sebesar $1 \mathrm{~m}, 2 \mathrm{~m}$ dan $1 \mathrm{~m}$ berturut-turut, sedangkan dimensi dyad adalah $0.2 \mathrm{~m}$ dan $0.75 \mathrm{~m}$. Disamping itu juga diperoleh besar konstanta kekakuan pegas untuk mengontrol bukaan katup sebesar 23.18 $\mathrm{kN} / \mathrm{m}$ dan torsi input sebesar $1083 \mathrm{Nm}$.

\section{DAFTAR PUSTAKA}

[1] Kim, J-W., Seo, T-W., and Kim, J-W., A new design methodology for four-bar linkage mechanisms based on derivations of coupler curve, Mechanisms and Machine Theory, Vol. 100, (2016), pp. 138-154.

[2] Eren, R. and Aydemir, A., An Approach to Kinematic Design of Four-bar Sley Drive Mechanisms in Weaving, The Journal of The Textile Institute, Vol. (95), pp. 193-205.

[3] Deshpandes, S, and Purwar, A., A TaskDriven Approach to Optimal Synthesis of Planar Four-Bar Linkages for Extended
Burmester Problem, Journal of Mechanisms and Robotics, Vol. 9, (2017), pp.1-9.

[4] Zhang, J., et al., J, Design and analysis of flexure revolute joint based on four-bar mechanism, Acta Astronautica, Vol. 151, (2018), pp. 420-431.

[5] Ganesan, G. and \& Sekar, M., Optimal synthesis and kinematic analysis of adjustable four-bar linkages to generate filleted rectangular paths, Mechanics Based Design of Structures and Machines, Mechanics Based Design of Structures and Machines, (2016), DOI: 10.1080/15397734.2016.1217780.

[6] Żbikowski, R., Galiński, C., and Pedersen, C. B., Four-Bar Linkage Mechanism for Insectlike Flapping Wings in Hover: Concept and an Outline of Its Realization. Journal of Mechanical Design, 127(4), (2005), 817. doi:10.1115/1.1829091

[7] Dharmawan, A. G., Hariri, H. H., Soh, G. S., Foong, S., and Wood, K. L. (2018). Design, Analysis, and Characterization of a TwoLegged Miniature Robot With PiezoelectricDriven Four-Bar Linkage. Journal of Mechanisms and Robotics, 10(2), 021003. doi:10.1115/1.4038970

[8] Farhat, N., Mata, V., Rosa, D., \& Fayos, J., A procedure for estimating the relevant forces in the human knee using a four-bar mechanism. Computer Methods in Biomechanics and Biomedical Engineering, 13(5), (2010), 577587. doi:10.1080/10255840903352540

[9] Hassan, A., \& Abomoharam, M., Design of a Single DOF Gripper based on Four-bar and Slider-crank Mechanism for Educational Purposes. Procedia CIRP, 21, 379-384, (2014). doi:10.1016/j.procir.2014.02.062 